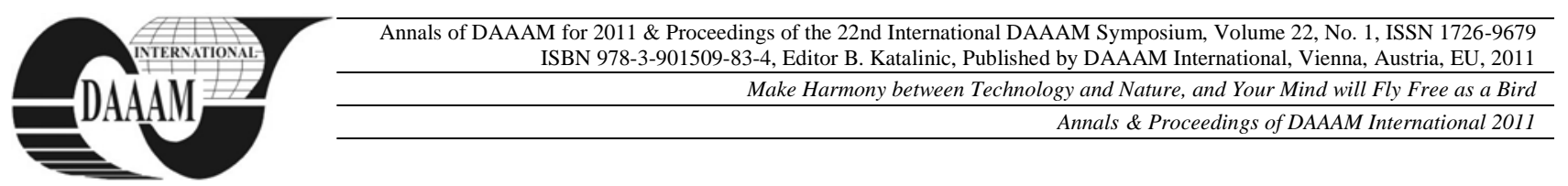

\title{
CREATIVE ACCOUNTING - THE POSSIBILITIES OF IMPACT OF THE VIEW OF FINANCIAL SITUATION OF ENGINEERING ENTERPRISES
}

\author{
DROZDOVA, A[ndrea]; HODULIKOVA, P[etra] \& SNIRCOVA, J[ana]
}

\begin{abstract}
Creative accounting can be defined as an approach that allows managing the information which is shown in the financial statements. In this paper we recall the possibilities of creative accounting in the conditions of Slovak accounting legislation and present on model example how the usage of creative accounting may influence the view of financial situation of engineering enterprise.
\end{abstract}

Key words: creative accounting, accounting legislation, financial situation of enterprise, inventories

\section{INTRODUCTION}

Data from the accounting do not serve as source of information only for management of enterprise, but also for various interest groups. On the basis of information which is recorded in financial statements, all of these interest groups not only evaluate the past of enterprise, but they may estimate its future development and accordingly then they may decide. This is the reason of why managers or owners have interest of manage, regulate the financial information which are contained in the financial statements. "Manage" accounting information in any case need not mean evading of accounting legislation. Many accounting systems, as an accounting system in the SR, provide the fields where it can apply creative accounting.

Aim of this paper is theoretically to define creative accounting and to show the possibilities of alternative presentation of economic information which accounting legislation in Slovakia affords and on the model example to present the impact of creative accounting on view of financial situation of enterprise.

\section{THEORETICAL DEFINITION OF CREATIVE ACCOUNTING}

Purposeful activity management, which is associated with considered application of procedures, methods and forms of balance of the entity's accounting in compliance with generally accepted accounting principles and basic assumptions of accounting, is named as the accounting policy. (Šlosárová, 2006) The management of company also must use the tools of accounting policy, so as to respect the laws and practices resulting from use of a particular accounting system. The system of regulation of accounting gives the compartment in which the company has the opportunities to use creative accounting.

The concept of creative accounting has become known mostly in connection with unfair practices and fraud in business practice. It creates the impression that it is always illegal to circumvent the law. Creative accounting may be based on statutory law and then it deals with searching for those procedures which will bring economic benefits for the entity within the law. (Miháleková, 2009) Different authors approach to the definition of creative accounting differently.

...Creative accounting is the practice of producing financial accounts that suit a particular purpose but do not really show the true and fair view...(*** 2010) According to Krupová
(Krupová, 2001), which deals with creative accounting in the Czech Republic, creative accounting is any deliberate adaptation of items of financial statements into the intended form. In Slovakia Tumpach deals with the issue of creative accounting and he defined this term as follows: „creative accounting is a dedicated collection and using of accounting practices, which leads to achieving the aims, which may be reported false financial position, financial performance or cash flows in an amount corresponding to the interests of managers".(Miháleková, 2009) Definitions of creative accounting are different, but all are consistent in that creative accounting is "an approach that allows the purposeful distortion of the economic status of the organization which is shown in the accounting."

\subsection{Possibilities of creative accounting in the Slovak accounting legislation}

Regulation of accounting is performed in single countries by different ways and in various extents by means of legal norms, accounting standards or their combination. Accounting in the Slovakia provides fewer fields for using of creative accounting than IAS / IFRS. The accounting system in the Slovak Republic is a system of regulating by the legal norms which are issued by the Ministry of Finance of the Slovak Republic. Although it is relatively strictly regulated by legislative norms, it offer for accounting entity several possibilities of accounting presentation of economic transactions, i.e. provide options where accounting entity can apply creative accounting.

In some cases, legislation defines multiple alternatives of accounting presentation of economic transactions (fields where legislation directly affords alternative), in others cases, the legislation leaves the option to display given fact according to reality in enterprise in competence of the entity, and in this case, the option of choice is depended on the subjective assessment of the entity (fields where the legislation accepts the subjective assessment of the entity).

\section{THE IMPACT OF CREATIVE ACCOUNTING ON VIEW OF FINANCIAL SITUATION OF ENTERPRISE}

On the model example, we will attempt to present the impact of one of listed above options of using of creative accounting on the view of the financial situation. We chose the field of valuation of decrease in the purchased inventories the same type. Exactly the inventories are a considerable part of assets in the engineering company. No small financial resources of enterprise are tying in them and they considerable influence the trend of view of financial performance of the company.

The inventories in consumption are valued at a price for which has been purchased. At the decrease in purchased inventories the entity has the option to choose. The entity can evaluate these inventories with fixed defined price in which they were acquired, with the price which is determined a weighted average of the acquisition cost, with FIFO. 
The impact on the view of the financial situation of enterprise at first we will assess by means of profit/loss and then in more detail by means of financial ratios.

Note:

Seeing that in the model example, we does not include all incomes and costs which affect profit/loss of enterprise during the accounting period, but we fixate the attention only to compare of incidence of the analyzed alternatives on the profit/loss of enterprise, we will be assessed the financial situation on the basis of difference between expected revenues and relevant costs. Consequently for quantification of the impacts we use the term "difference", not profit/loss.

\section{Example}

The engineering enterprise buys material from several suppliers. In the month of February 2011 there was the initial inventory of 100 pieces of blocks of material for 9.80 EUR. The enterprise expects revenues of 15000 EUR for month of February. Total inventories of material of enterprise are on average $10 \%$ from assets. Carried purchases and consumptions of material in February are chronologically arranged in Tab. 1.

\begin{tabular}{|l|c|c|c|}
\hline & Pieces & EUR/block & $\begin{array}{l}\text { Value of } \\
\text { inventories }\end{array}$ \\
\hline 1.2. Initial inventory & 100 & 9.80 & 980 \\
\hline 3.2. Purchase & 350 & 9.83 & 3441 \\
\hline 5.2. Purchase & 450 & 9.95 & 4478 \\
\hline $\begin{array}{l}\text { 8. 2. Consumption of } \\
\text { material }\end{array}$ & 650 & - & - \\
\hline 15.2. Purchase & 650 & 9.95 & 6468 \\
\hline $\begin{array}{l}\text { 26. 2. Consumption } \\
\text { of material }\end{array}$ & 750 & - & - \\
\hline
\end{tabular}

Tab. 1 Purchases and consumptions of material in the month of February

Tab. 2 shows the valuation of decrease in the inventories and amount of inventories at the end of February according to particular methods. The consumption of material and the amount of the difference at expected revenues are also listed in this table.

\begin{tabular}{|l|c|c|c|}
\hline & FIFO & $\begin{array}{c}\text { Continuous } \\
\text { weighted } \\
\text { average }\end{array}$ & $\begin{array}{c}\text { Periodic } \\
\text { weighted } \\
\text { average }\end{array}$ \\
\hline $\begin{array}{l}\text { Consumption 8.2. }= \\
700 \text { pieces }\end{array}$ & 6410,5 & 6428,5 & 6422,0 \\
\hline $\begin{array}{l}\text { Consumption 26.2. }= \\
\text { 650 pieces }\end{array}$ & 7462,5 & 7447,5 & 7410,0 \\
\hline $\begin{array}{l}\text { Consumption of } \\
\text { material in February }\end{array}$ & $\mathbf{1 3 ~ 8 7 3 , 0}$ & $\mathbf{1 3 ~ 8 7 6 , 0}$ & $\mathbf{1 3 8 3 2 , 0}$ \\
\hline $\begin{array}{l}\text { Number of inventories } \\
\text { at the end of February }\end{array}$ & 1492,5 & 1489,5 & 1533,5 \\
\hline $\begin{array}{l}\text { Difference at expected } \\
\text { revenues }\end{array}$ & 1127,0 & 1124,0 & 1168,0 \\
\hline
\end{tabular}

Tab. 2 Valuation of the decrease in material according to particular methods (all values are shown in EUR)

Removal of the inventory is accounted for by consumption (cost item), that means that it decrease the profit/loss of enterprise. The amount of valuation of consumption of inventories is different for each of the methods. It is also necessary to adduce that the method of valuation of inventories by their removal affect in addition of the costs also the amount of inventory which is recognized in the balance sheet. The higher valuation of inventories by their removal, the lower value of inventories will be recognized in balance sheet.

In the case of an enterprise which wants to reduce its costs and it assume that the prices of purchased inventories will be put up, the most advantageous method is weighted average periodical. By contrast, if it assumes that the prices of purchased inventories will be decline, the most advantageous method is continuous weighted average by which costs of consumption of material will be the lowest.

On the measuring and evaluating of financial situation of enterprise we can use except profit/loss also the financial ratios. For our model example, we chose financial ratios whose value is affected with data which are used in the example. Tab. 3 shows the selected financial ratios. Their values are affected with the consumption of inventories, value of inventories, revenues and assets.

\begin{tabular}{|l|c|c|c|}
\hline Financial ratios & FIFO & $\begin{array}{c}\text { Continuous } \\
\text { WA }\end{array}$ & $\begin{array}{c}\text { Periodic } \\
\text { WA }\end{array}$ \\
\hline $\begin{array}{l}\text { Profitability of revenues (\%) } \\
\text { (difference/revenues) }\end{array}$ & 7,51 & 7,49 & 7,79 \\
\hline $\begin{array}{l}\text { Profitability of assets (\%) } \\
\text { (difference/assets) }\end{array}$ & 10,93 & 10,90 & 11,28 \\
\hline $\begin{array}{l}\text { Efficiency of assets } \\
\text { (coefficient) } \\
\text { (revenues/residual value of } \\
\text { assets) }\end{array}$ & 1,454 & 1,455 & 1,449 \\
\hline $\begin{array}{l}\text { Efficiency of inventories } \\
\text { (coefficient) } \\
\text { (revenues/residual value of } \\
\text { inventories) }\end{array}$ & 10,050 & 10,070 & 9,782 \\
\hline
\end{tabular}

Tab. 3 Selected financial indicators of organization

As we can seen from the table, different valuation of decrease in the purchased inventories the same type affects also the amount of selected financial ratios, especially indicators of profitability. This means that this different valuation affects especially the view of financial performance of enterprise. The amount of difference respectively the impact depends on the representation of the specific item of property in total assets.

\section{CONCLUSION}

Creative accounting can be defined as an approach that allows the purposeful misrepresentation of the economic situation of the enterprise which is shown in the accounting. The accounting system in the Slovak Republic, although is regulated by legislative norms, provides compartment for the entity in which may influence the view of financial situation of enterprise. In the article we have shown on model example how alternative of accounting solution may influence the profit/loss of engineering enterprise, which is presented to external and internal users, who evaluate the financial situation also on the basis of its.

\section{REFERENCES}

Miháleková, A. (2009). Kreatívne účtovníctvo a možnosti jeho detekcie (Creative accounting and the possibility of its detection). Bratislava: The University of Economics in Bratislava. Slovakia, Faculty of Economic Informatics, Department of Accountancy and Auditing, pg. 66, diploma thesis

*** (2010) http://www.creativeaccounting.net/what-is-creativeaccounting - What is Creative Accounting?, Accessed: 2010-03-05

Šlosárová, A. (2006). Analýza účtovnej závierky (Analysis of financial statements). IURA Edition, ISBN: 80-8078-07006, Bratislava, pg. 478

Krupová, L. (2001) Kreativni účetnictví, Zneuživaní účetnictví - možnosti a meze (Creative Accounting, Imposition of Accounting - possibilities and limits). Komora auditoru ČR, ISBN 9788090285521 , Praha, pg. 64

Zákon č. 431/2002 Z. z. o účtovníctve (Law about accounting No. 431/2002 Coll.) 